\title{
Bactericidal activity of the new 4-quinolones DU-6859a and DV-7751a
}

\author{
I. MORRISSEY and J. T. SMITH*
}

Chemotherapy Research Unit, University of East London, Romford Road, London E15 4 LZ and * Microbiology Section, Department of Pharmaceutics, The School of Pharmacy, University of London, Brunswick Square, London WC1N 1 AX

\begin{abstract}
Summary. The bactericidal activity of two new 4-quinolones, DU-6859a and DV-7751a, was investigated against strains of Escherichia coli, Staphylococcus aureus, S. epidermidis, Streptococcus pneumoniae and Enterococcus faecalis. DU-6859a and DV-7751a were more bactericidal than any 4-quinolone tested previously. Furthermore, DU-6859a was unique among 4-quinolones in being able to kill Ent. faecalis after incubation for only $3 \mathrm{~h}$ in nutrient broth. The bactericidal mechanisms of DV-7551 a were similar to those of other 4-quinolones, but, uniquely, DU-6859a possessed additional bactericidal mechanisms against both Str. pneumoniae and Ent. faecalis. This may explain the unusually potent bactericidal activity of this agent against these species. These results show that DU-6859a is a unique extendedspectrum 4-quinolone, which should prove to be superior to established 4-quinolones.
\end{abstract}

\section{Introduction}

Preliminary studies have suggested that DU-6859a and DV-7751a may be significantly more active than currently available 4-quinolones against a wide range of bacteria. ${ }^{1,2}$ To investigate this claim further, their bactericidal activity was studied against strains of Escherichia coli, Staphylococcus aureus, S. epidermidis, Streptococcus pneumoniae and Enterococcus faecalis.

The bactericidal activity of 4-quinolones has been described with respect to three mechanisms of action, termed A, B and C. Mechanism A requires the bacteria to be undergoing multiplication and protein or RNA synthesis. It occurs with all 4-quinolones, except when high concentrations are used against Pseudomonas aeruginos $a,{ }^{3}$ and is the sole bactericidal mechanism of older 4-quinolones, such as nalidixic and oxolinic acids. ${ }^{4}$ Mechanism $\mathbf{B}$ is an additional mechanism of several modern 4-quinolones including ofloxacin, ciprofloxacin, ${ }^{5}$ lomefloxacin, ${ }^{6}$ levofloxacin, ${ }^{7}$ fleroxacin, pefloxacin, ${ }^{8}$ PD $131628^{9}$ and sparfloxacin. ${ }^{10}$ Unlike mechanism A, mechanism B allows bactericidal activity against non-dividing bacteria and does not require active protein or RNA synthesis. ${ }^{4} \mathrm{~A}$ related bactericidal mechanism, termed $B_{1}$, has been identified with clinafloxacin (PD127,391.) ${ }^{11}$ Although it does not require active protein or RNA synthesis, mechanism $B_{1}$, is nevertheless lost against non-dividing

Received 21 Oct. 1994; revised version accepted 11 Dec. 1994. bacteria. ${ }^{11}$ Mechanism C, which has so far been found only with norfloxacin ${ }^{12}$ and enoxacin, ${ }^{6}$ does not require bacterial multiplication, but does need active protein and RNA synthesis.

Possession of additional mechanisms against one bacterial species does not guarantee their occurrence against others. For example, ciprofloxacin has mechanism B against $E$. coli,${ }^{5}$ but possesses only mechanism A against staphylococci. ${ }^{13}$ Ofloxacin, on the other hand, exerts mechanism B against both $E$. coli and staphylococci, ${ }^{5,13}$ as does levofloxacin. ${ }^{7}$ All 4quinolones tested so far possess only bactericidal mechanism A against Str. pneumoniae ${ }^{14}$ and Ent. faecalis, ${ }^{15}$ and these species represent a considerable weakness in the bactericidal spectrum of 4-quinolones. This is especially pertinent for Ent. faecalis, for which the rate of bactericidal activity of 4-quinolones is slower than for other gram-positive bacteria. ${ }^{9,15}$ This study aimed to characterise the bactericidal mechanisms of DU-6859a and DV-7751a and to determine if they had any advantage over earlier agents against pneumococci and enterococci.

\section{Materials and methods}

\section{Bacterial strains}

E. coli $\mathrm{KL} 16,{ }^{16} S$. epidermidis SK $360,{ }^{13} S$. aureus E3T, ${ }^{17}$ Str. pneumoniae C3LN4 ${ }^{18}$ and Ent. faecalis 
ATCC $19433^{15}$ were used. These species and strains were chosen because of their previous use in determining the bactericidal activity and mechanisms of action of other 4-quinolones.

\section{Antibacterial agents}

DU-6859a and DV-7751a (Daiichi Pharmaceutical Co., Japan) were initially dissolved in $0.1 \mathrm{M} \mathrm{NaOH}$ at $10 \mathrm{mg} / \mathrm{ml}$ and immediately diluted with sterile distilled water. Chloramphenicol (Parke-Davis, Pontypool, Gwent) was prepared initially in methanol and diluted further in sterile distilled water.

\section{Determination of the bactericidal activities of $D U-6859 a$ and $D V-7751 a$}

Ten $\mathrm{ml}$ of Nutrient Broth No. 2 (Unipath Basingstoke, Hants) was inoculated with bacteria and then incubated overnight at $37^{\circ} \mathrm{C}$ to provide organisms for study. For Str. pneumoniae cultures, the nutrient broth was supplemented with laked horse blood (Unipath) $7 \%$.

To study bactericidal activity, sterile doublestrength nutrient broth first was dispensed in 5-ml volumes in sterile $1 \mathrm{oz}$ bottles. The aqueous 4quinolone and sterile distilled water were then added to give a final volume of $9.8 \mathrm{ml}$, and a drug concentration between 0.015 and $90 \mathrm{mg} / 1$. When Str. pneumoniae was tested, laked horse blood was added to a final concentration of $7 \%$. When required, aqueous chloramphenicol was also added to a final concentration of $20 \mathrm{mg} / 1$ or $2.5 \mathrm{mg} / 1$ for $S t r$. pneumoniae. These concentrations of chloramphenicol were bacteriostatic (data not shown). The bottles were then warmed for at least $15 \mathrm{~min}$ in a waterbath at $37^{\circ} \mathrm{C}$, after which $0.2 \mathrm{ml}$ of overnight culture, containing c. $2.5 \times 10^{8} \mathrm{cfu} / \mathrm{ml}$, was added. Viable counts at time zero thus were $c .5 \times 10^{6} \mathrm{cfu} / \mathrm{ml}$.

In some experiments $\mathrm{PBS}(\mathrm{NaCl} 0.9 \%$ in $0.025 \mathrm{M}$ sodium phosphate buffer, $\mathrm{pH} 7 \cdot 4$ ), replaced nutrient broth. In these cases the overnight cultures used were harvested by centrifugation at $4000 \mathrm{rpm}$ for $15 \mathrm{~min}$, washed, and then resuspended in $10 \mathrm{ml}$ of sterile PBS to prevent nutrient carry-over. To prevent autolysis of Str. pneumoniae, horse serum (Unipath) $7 \%$ was added when this organism was studied.

All incubations were for $3 \mathrm{~h}$ at $37^{\circ} \mathrm{C}$, except that Ent. faecalis cultures also were incubated for 6 and $24 \mathrm{~h}$. Experiments were stopped by adding $10 \mathrm{ml}$ of sterile ice-cold nutrient broth, after which the cells were harvested by centrifugation at $4000 \mathrm{rpm}$ for $15 \mathrm{~min}$, then resuspended in $10 \mathrm{ml}$ of sterile nutrient broth at room temperature to prevent drug carry-over. Viable counts were determined by serial dilution in sterile nutrient broth at room temperature, and $0 \cdot 1-\mathrm{ml}$ amounts of the dilutions were spread on nutrient agar, supplemented with laked horse blood $7 \%$ for Str. pneumoniae. Owing to the strong bactericidal activity of DU-6859a against $E$. coli, a total volume of $1 \mathrm{ml}$ was spread in three samples of $0.3 \mathrm{ml}$ and one of $0.1 \mathrm{ml}$ when this agent was tested at concentrations between 0.5 and $3 \mathrm{mg} / 1$. All plates were incubated for 2 days at $37^{\circ} \mathrm{C}$ before the colonies were counted.

\section{Results}

A biphasic dose response occurred with DU-6859a against $E$. coli, with an optimum bactericidal concentration (OBC) of $0.9 \mathrm{mg} / 1$ (fig. 1). Most killing occurred in normal nutrient broth culture, but considerable killing was still achieved when a bacteriostatic concentration of the protein synthesis inhibitor chloramphenicol was added or when the bacteria were resuspended in PBS prior to exposure to the quinolone. Similar behaviour was seen for DV-7751a against $E$. coli and for both DU-6859a or DV-7751a against $S$. aureus or $S$. epidermidis (not shown).

The proportions of E. coli, S. aureus, S. epidermidis and Str. pneumoniae cells that survived exposure to DU-6859a or DV-7751a at OBC are shown in the table. Both drugs had OBCs of $0.9 \mathrm{mg} / 1$ for $E$. coli, but DV-7751a had lower OBCs than DU-6859a for staphylococci. The extent of killing by either DU6859a or DV-7751a at OBC in nutrient broth was greater than with any 4-quinolone studied previously. In nutrient broth, DU-6859a was 58 times more bactericidal than DV-7751a against $E$. coli and 19 times more so against $S$. epidermidis, but both 4-quinolones had approximately equal bactericidal activity at $\mathrm{OBC}$ against $S$. aureus. However, DU-6859a was more bactericidal than DV-7751a against all three of these species in nutrient broth containing chloramphenicol, or in PBS.

DV-7751a was most bactericidal against Str.

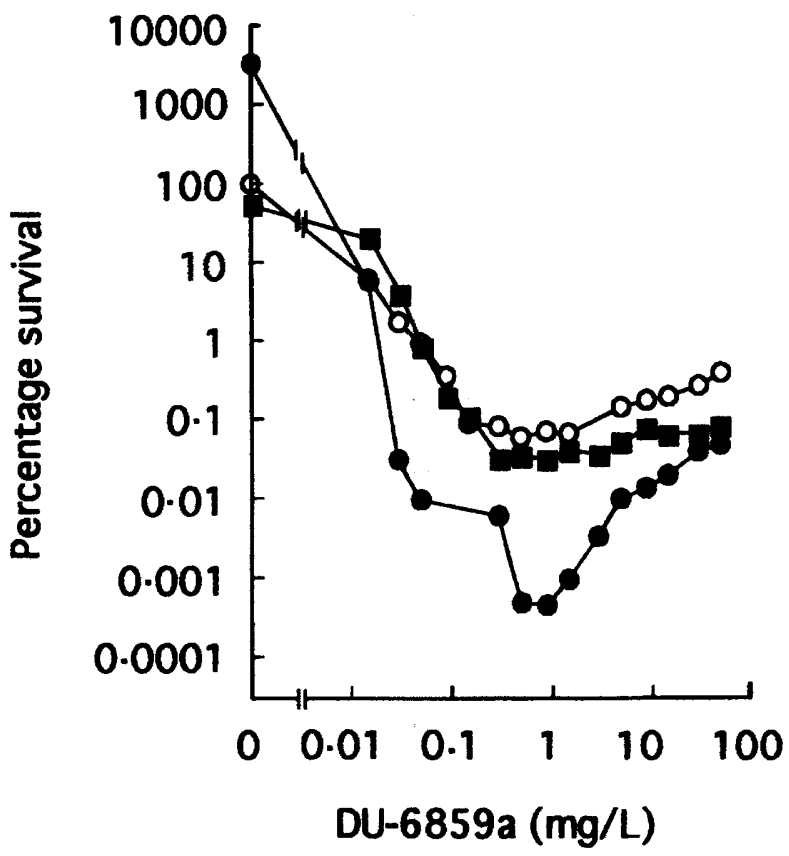

Fig. 1. Survival of $E$. coli KL16 after exposure to DU-6859a for $3 \mathrm{~h}$ in nutrient broth $(O)$, phosphate-buffered saline $(O)$ or nutrient broth containing chloramphenicol $20 \mathrm{mg} / \mathrm{l}(\mathbf{0})$ at $37^{\circ} \mathrm{C}$. 
Table. Survival rates of bacteria exposed to DU-6859a or DV-7751a at OBC for $3 \mathrm{~h}$ at $37^{\circ} \mathrm{C}$

\begin{tabular}{|c|c|c|c|c|}
\hline \multirow[b]{2}{*}{ 4-Quinolone } & \multirow[b]{2}{*}{$\begin{array}{l}\text { Organism } \\
(\text { OBC }, \mathrm{mg} / \mathrm{l})\end{array}$} & \multicolumn{3}{|c|}{ Percentage survival in } \\
\hline & & $\begin{array}{c}\text { nutrient } \\
\text { broth* }\end{array}$ & $\begin{array}{c}\text { nutrient } \\
\text { broth* plus } \\
\text { chloramphenicol }\end{array}$ & PBS $\dagger$ \\
\hline \multirow[t]{4}{*}{ DU-6859a } & E. coli $(0 \cdot 9)$ & 0.00045 & $0 \cdot 028$ & 0.07 \\
\hline & $S$. aureus $(3 \cdot 0)$ & 0.0043 & 0.09 & $0 \cdot 18$ \\
\hline & S. epidermidis $(3.0)$ & 0.0013 & $0 \cdot 28$ & $2 \cdot 13$ \\
\hline & Str. pneumoniae $(0 \cdot 9)$ & 0.095 & $0 \cdot 14$ & 0.41 \\
\hline \multirow[t]{4}{*}{ DV-7751a } & E. coli $(0.9)$ & $0 \cdot 026$ & $0 \cdot 70$ & $1 \cdot 29$ \\
\hline & S. aureus (0.9) & 0.0046 & $0 \cdot 21$ & 1.67 \\
\hline & S. epidermidis $(1-5)$ & 0.025 & 5.83 & $11 \cdot 94$ \\
\hline & Str. pneumoniae $(1 \cdot 5)$ & $0 \cdot 17$ & 3.94 & $10 \cdot 70$ \\
\hline
\end{tabular}

*For Str. pneumoniae laked horse blood $7 \%$ was added.

+For Str. pneumoniae horse serum $7 \%$ was added.
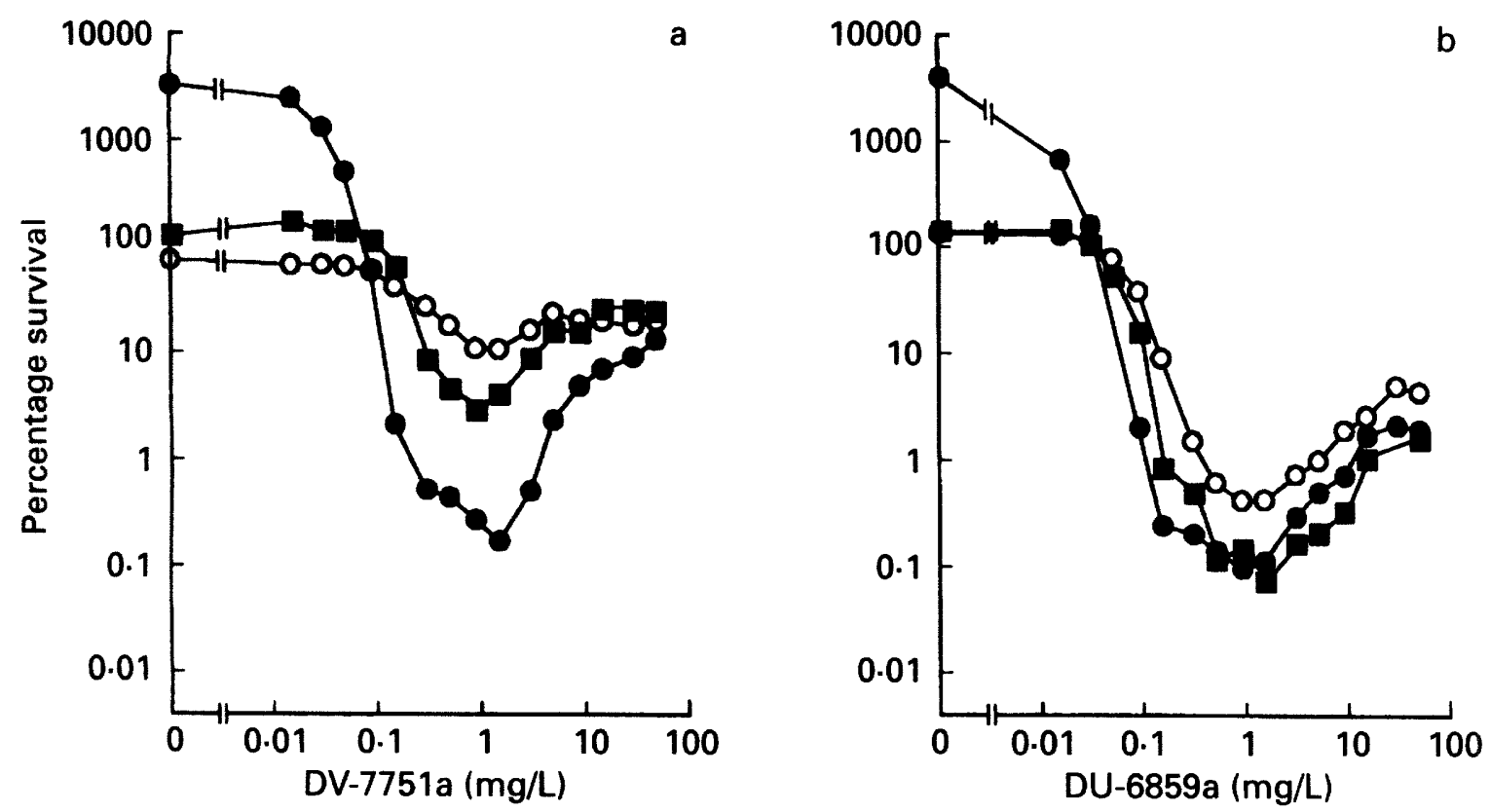

Fig. 2. Survival of Str. pneumoniae C3LN4 after exposure to: a, DV-7751a or b, DU-6859a for 3 h in nutrient broth (O), phosphate-buffered saline $(\mathrm{O})$ or nutrient broth containing chloramphenicol $2.5 \mathrm{mg} / \mathrm{l}(\mathrm{a})$ at $37^{\circ} \mathrm{C}$.

pneumoniae in blood broth and was less so when a bacteriostatic concentration of chloramphenicol was added, or when tested in PBS plus horse serum 7\%. Nevertheless, some killing did occur under these latter conditions (fig. 2a). In contrast, DU-6859a was equally potent against pneumococci in blood broth whether or not chloramphenicol was added (fig. 2b), and was only slightly less bactericidal in PBS plus horse serum. This strong bactericidal activity of DU-6859a against nondividing Str. pneumoniae is unique among 4-quinolone antibacterial agents.

Weak bactericidal activity was seen for DV-7751a against Ent. faecalis after incubation for $3 \mathrm{~h}$ in nutrient broth at $37^{\circ} \mathrm{C}$, but more significant killing was seen only after incubation for 6 or $24 \mathrm{~h}$ (fig. 3a). By contrast, DU-6859a had good bactericidal activity against this organism within $3 \mathrm{~h}$ in nutrient broth at $37^{\circ} \mathrm{C}$ (fig. $3 \mathrm{~b}$ ), although still more killing was observed after 6 or $24 \mathrm{~h}$. This rapid bactericidal activity of DU-6859a against Ent. faecalis is also unique among 4-quinolones. When bactericidal activity was tested against non-dividing enterococci in PBS, no significant killing occurred with DV-7751a up to $90 \mathrm{mg} / \mathrm{L}$, even after $24 \mathrm{~h}$ (fig. 4a), nor, during exposure periods shorter than $24 \mathrm{~h}$, in nutrient broth containing chloramphenicol. DU-6859a did not kill Ent. faecalis in PBS even after 24 h (fig. 4b); but, unlike with DV-7751a, bactericidal activity was seen in nutrient broth containing chloramphenicol, with 10,1 and $0.01 \%$ survivors remaining after incubation for 3,6 and $24 \mathrm{~h}$, respectively. These results show that DU-6859a, unlike DV-7751a, possessed another bactericidal mechanism, in addition to mechanism $\mathrm{A}$, against Ent.faecalis, and may explain the compound's rapid bactericidal rate against this species. 

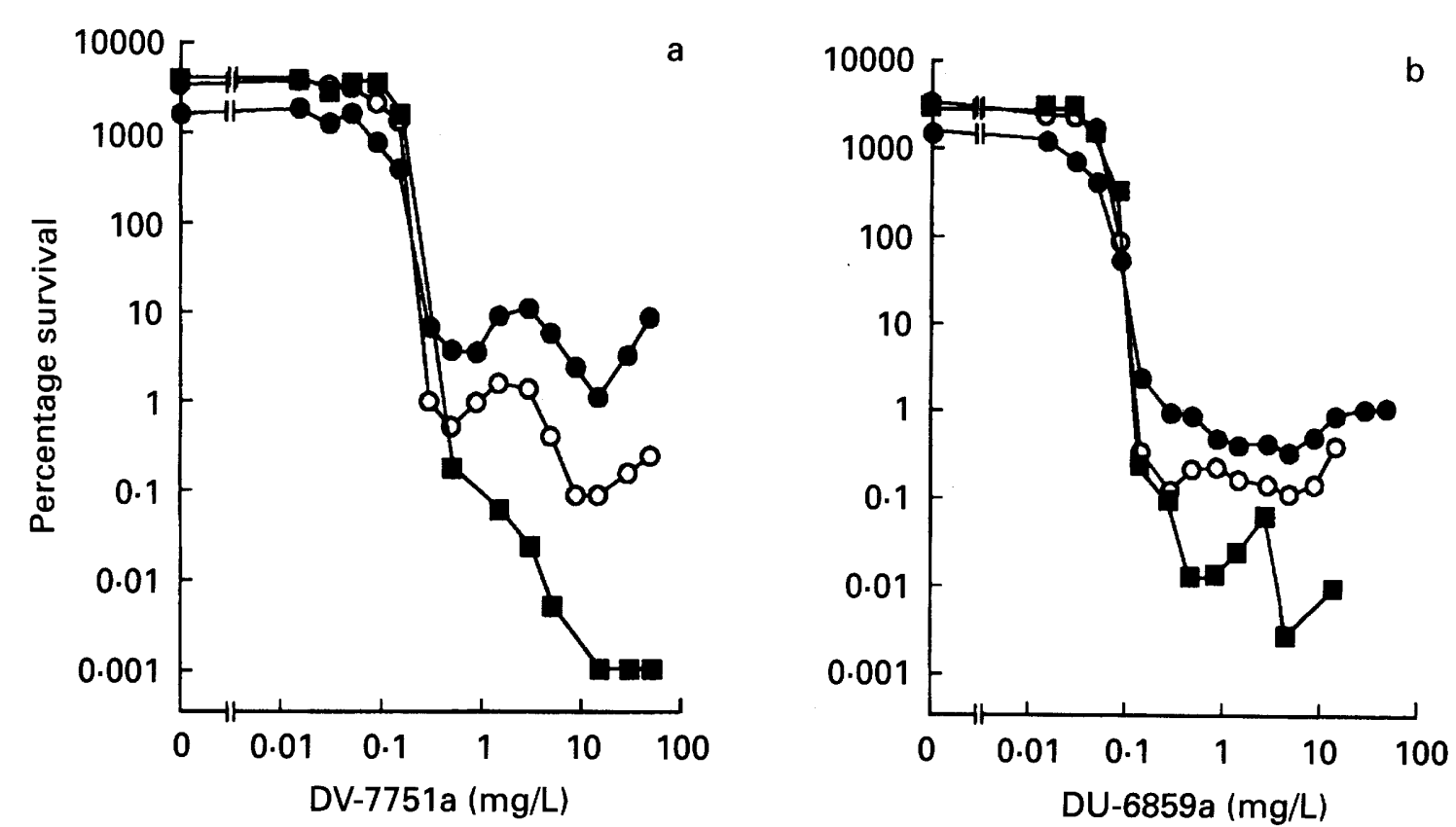

Fig. 3. Survival of Ent. faecalis ATCC 19433 after exposure to: a, DV-7751a or b, DU-6859a for $3 \mathrm{~h}(\mathbf{O}), 6 \mathrm{~h}(\mathrm{O})$ or $24 \mathrm{~h}(\boldsymbol{\square})$ in nutrient broth at $37^{\circ} \mathrm{C}$.
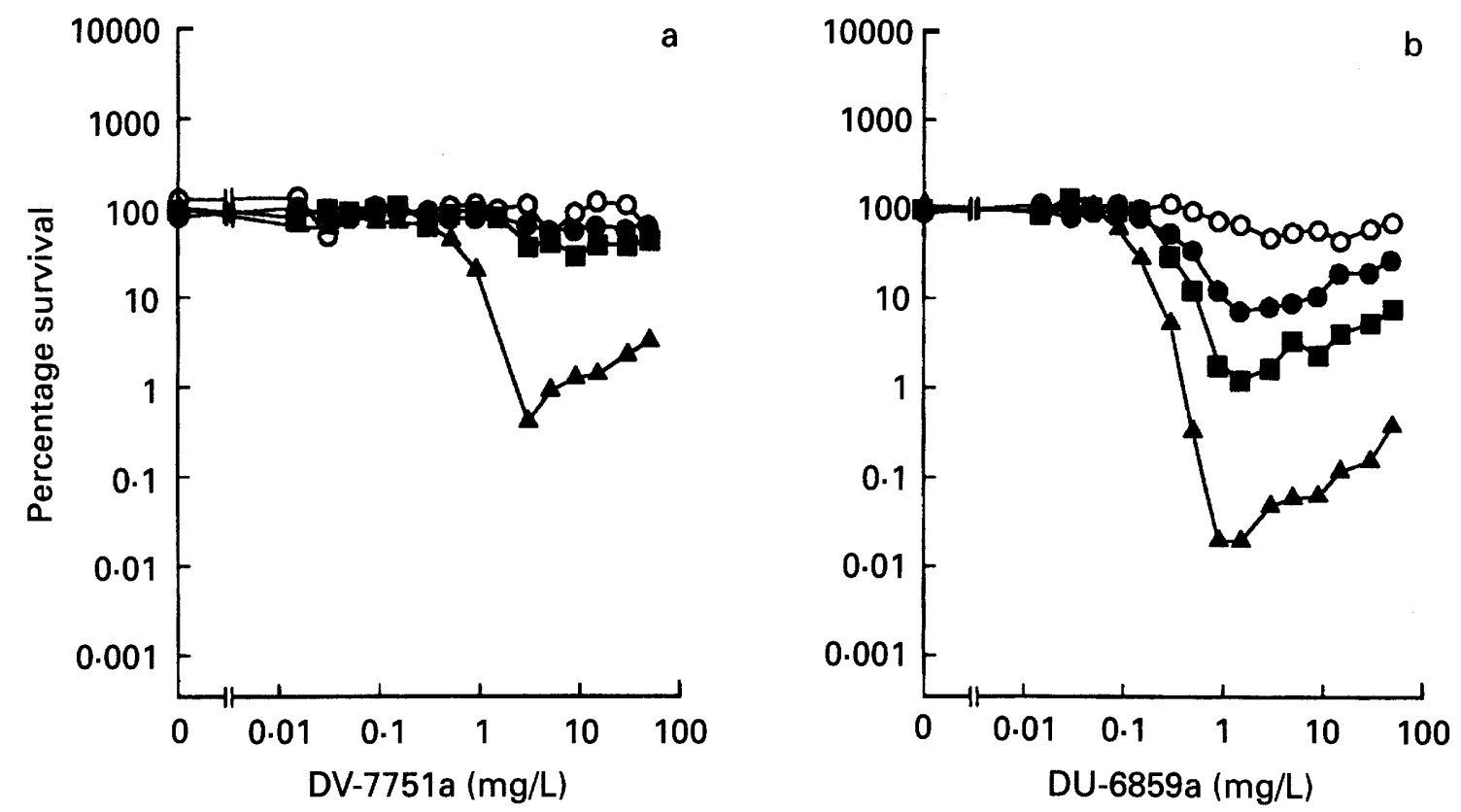

Fig. 4. Survival of Ent. faecalis ATCC 19433 after exposure to : a DV-7751a or b, DU-6859a for $24 \mathrm{~h}$ in phosphate-buffered saline (O), or $3 \mathrm{~h}$

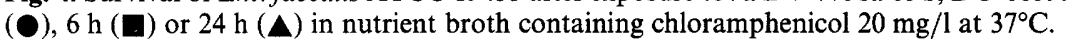

\section{Discussion}

The bactericidal activity and mechanisms of many 4-quinolones have been studied previously. ${ }^{4-15}$ In this study, the bactericidal activities and mechanisms of action of two new 4-quinolones, DU-6859a and DV7751a, were investigated against the same test strains used in these earlier studies. DV-7751a and DU-6859a, like many other 4-quinolones, displayed another bactericidal mechanism, in addition to mechanism $\mathrm{A}$, against $E$. coli, $S$. aureus and $S$. epidermidis. This appeared to be mechanism $\mathrm{B}$, because both drugs could kill bacteria in the absence of active protein or RNA synthesis and when the bacteria were not multiplying.
DV-7751a had very similar OBCs against $E$. coli, $S$. aureus and $S$. epidermidis. This is unusual among 4quinolones, and has only been seen previously with sparfloxacin. ${ }^{10}$ DU-6859a, on the other hand, was more like other 4-quinolones in that its $\mathrm{OBC}$ for $E$. coli was about three-fold lower than for either staphylococcal species. However, comparison of OBCs alone may not allow a fair assessment of DV-7751a and DU-6859a because both drugs were extremely bactericidal at even lower concentrations. This was especially marked for DU-6859a against $E$. coli, where a modification of the usual viable counting method was necessary to enumerate the few survivors.

OBCs of both new quinolones against Str. pneumoniae were considerably lower than those of 
other 4-quinolones. ${ }^{14}$ Moreover, both DV-7751a and DU-6859a were able to kill Str. pneumoniae in the absence of active protein or RNA synthesis, or when the bacteria were not multiplying, indicating the presence of mechanism B. All 4-quinolones previously tested showed only mechanism $\mathrm{A}$ against this species. ${ }^{14}$ The occurrence of mechanism $B$ may explain the greater bactericidal activity of these drugs for pneumococci and may be extremely useful in the treatment of infections, where the bacteria may not be dividing. Mechanism B was particularly strong with DU-6859a, where essentially the same extent of killing was seen against Str. pneumoniae in blood broth whether or not a bacteriostatic concentration of chloramphenicol was added. Possession of such a powerful mechanism B suggests that DU-6859a might be used in combination with those antibacterial agents that inhibit bacterial protein synthesis, whereas the bactericidal activity of other 4-quinolones may be seriously impaired by inhibitors of protein synthesis, as has been shown with levofloxacin. ${ }^{19}$ Such combination therapy might be desirable to prevent the development of bacterial resistance.

Previous 4-quinolones have had very slow rates of bactericidal activity against Ent. faecalis ${ }^{9}{ }^{15}$ although, contrary to a recent claim, ${ }^{20}$ they are not merely bacteriostatic against these organisms. In this study a slow rate of bactericidal activity was seen with DV-7751a, although reasonable killing occurred after exposure for $6 \mathrm{~h}$, whereas other 4-quinolones require

\section{References}

1. Sato K, Hoshino K. Tanaka M, Hayakawa I, Osada Y. Antimicrobial activity of $\mathrm{DU}-6859$, a new potent fluoroquinolone, against clinical isolates. Antimicrob Agents Chemother 1992; 36: 1491-1498.

2. Tanaka M, Hoshino K. Ishida H, Sato K. Hayakawa I, Osada Y. Antimicrobial activity of DV-7751a, a new fluoroquinolone. Antimicrob Agents Chemother 1993; 37: 2112-2118.

3. Morrissey I, Smith JT. The activity of 4-quinolones against Pseudomonas aeruginosa. Arzneim-Forsch/Drug Res 1994: 44: $1157-1161$

4. Lewin CS, Morrissey I. Smith JT. The mode of action of quinolones: the paradox in activity of low and high concentrations and activity in the anaerobic environment. Eur J Ctin Microbiol Infect Dis 1991; 10: 240-248.

5. Ratcliffe NT, Smith JT. Ciprofloxacin and ofloxacin exhibit a rifampicin-resistant bactericidal mechanism not detectable in other 4-quinolone antibacterial agents. $J$ Pharm Pharmacol 1984; 36 Suppl: 59P.

6. Lewin CS, Amyes SGB, Smith JT. Bactericidal activity of enoxacin and lomefloxacin against Escherichia coli KL16. Eur J Clin Microbiol Infect Dis 1989; 8: 731-733.

7. Lewin CS. Amyes SGB. The bactericidal activity of DR-3355, an optically active isomer of ofloxacin. $J$ Med Microbiol $1989 ; 30: 227-231$

8. Lewin CS, Amyes SGB. Conditions required for the bactericidal activity of fleroxacin and pefloxacin against Escherichia coli KLl6. J Med Microbiol 1990; 32: 83-86. exposure for $24 \mathrm{~h}$ to act significantly. ${ }^{9,15}$ Moreover, DV-7751a, like other 4-quinolones, possessed only bactericidal mechanism A against Ent. faecalis. DU6859a, on the other hand, was bactericidal against Ent. faecalis within $3 \mathrm{~h}$ and had a bactericidal mechanism additional to mechanism $\mathrm{A}$. This additional mechanism was neither $\mathrm{B}$ nor $\mathrm{C}$ because, although killing occurred when the bacteria were incapable of active protein or RNA synthesis, it was not achieved against non-multiplying bacteria. Thus, this additional mechanism appears to be mechanism $B_{1}$, which has been reported previously only for clinafloxacin against $E$. coli, $S$. aureus and S. epidermidis. ${ }^{11}$

To conclude, DV-7751a appears similar in its bactericidal activity and bactericidal mechanisms of action to other available fluoroquinolones, except for having enhanced anti-pneumococcal activity and very powerful bactericidal activity against $S$. aureus. It may perhaps acquire a special role against these species. Overall, however, DU-6859a was a more potent agent, and was more bactericidal than any other 4-quinolone investigated with these test bacteria. The bactericidal activity of DU-6859a was particularly powerful against Str. pneumoniae and Ent. faecalis, perhaps because of the occurrence of bactericidal mechanisms $B$ or $B_{1}$ in addition to mechanism $A$. If brought into clinical use, DU-6859a would be the most active 4-quinolone available.

We are grateful to Daiichi Pharmaceutical Co. Ltd. for their sponsorship of a post-doctoral Fellowship for I.M.

9. Lewin CS. Antibacterial activity of a 1,8-naphthyridine quinolone, PD131628. J Med Microbiol 1992; 36: 353-357.

10. Lewin CS, Morrissey I, Smith JT. The bactericidal activity of sparfloxacin. J Antimicrob Chemother 1992; 30: 625-632.

11. Lewin CS, Amyes SGB. Bactericidal action of PD 127, 391, an enhanced spectrum quinolone. J Med Microbiol 1990; 33: $67-70$.

12. Ratcliffe NT, Smith JT. Norfloxacin has a novel bactericidal mechanism unrelated to that of other 4-quinolones. $J$ Pharm Pharmacol 1985; 37 Suppl: 92P.

13. Lewin CS, Smith JT. Bactericidal mechanisms of ofloxacin. $J$ Antimicrob Chemother 1988; 22 Suppl C: 1-8.

14. Morrissey I, Smith JT. Activity of quinolone antibacterials against Streptococcus pneumoniae. Drugs 1993; 45 Suppl 3: 196-197.

15. Lewin CS, Morrissey I, Smith JT. The fluoroquinolones exert a reduced rate of kill against Enterococcus faecalis. J Pharm Pharmacol 1991 ; 43: 492-494.

16. Smith JT. Awakening the slumbering potential of the 4 quinolone antibacterials. Pharm $J$ 1984; 233 ; 299-305.

17. Knox R, Smith JT. The nature of penicillin resistance in staphylococci. Lancet $1961 ; 2$ : 520-522.

18. Smith JT. Mutation rates to 4-quinolone resistance. ArzneimittelForschung Res 1990; 40: 65-68.

19. Morrissey I, Khatri N, Leighton H, Mustafa N, Nathan C, Smith JT. The interaction between the 4-quinolone $\mathrm{S}(-)$ ofloxacin and other antibacterials against Streptococcus pneumoniae. J Pharm Pharmacol 1992; 44 Suppl: 1057.

20. Piddock LJV. New quinolones and gram-positive bacteria. Antimicrob Agents Chemother 1994; 38: 163-169. 